\title{
Fish Ecogenotoxicology: An Emerging Science, an Emerging Tool for Environmental Monitoring and Risk Assessment
}

\section{Akpoilih BU*}

Department of Animal Science and Fisheries, University of Port Harcourt, Nigeria

\begin{abstract}
Ecogenotoxicology (genetic ecotoxicology) is an approach that applies the principles and techniques of genetic toxicology to assess the potential effects of environmental pollution in the form of genotoxic agents on the health of the ecosystem. Contrary to human toxicology studies which focus on the fate of the individual, ecogenotoxicology evaluates the consequences of genotoxicants for population sizes and structure, but applies the principles of genetic toxicology in hazard and risk assessment. Genetic hazard assessment, thus, deals with changes in genetic material of organisms, either human or other natural origin. Several reviews demonstrate the presence and potency of genotoxins from a broad range of industrial and municipal effluents. There is a close association of DNA damage, mutation, and induction of various types of cancer. Fish serves as useful genetic model for the evaluation of pollution in aquatic ecosystems. Fish species from contaminated areas initiated studies in the aquatic environment and evidence is growing that environmental mutagens can reduce the reproductive success of populations. Different genotoxicity tests and their applications to environmental monitoring and assessment have been variously reported in fish. This review paper, thus, examines the use of ecogenotoxicology in environmental monitoring, the role of fish in genotoxicity testing of pollutants, genetic basis in genotoxicological assessment, cur rent methods of ecogenotoxicological hazard assessment using fish in vitro and in vivo, and their applications to environmental monitoring as well as recent advances in the field of fish ecogenotoxicology. Limitations and recommendations for further research on the use of ecogenotoxicology were also highlighted.
\end{abstract}

Keywords: Ecogenotoxicology; Environmental monitoring; Risk assessment; DNA damage; Genotoxicity tests

\section{Introduction}

Pollution of the environment has become a major concern of society [1]. One of the most sensitive concerns is the potential for exposure to substances that are genotoxic. A genotoxic chemical or physical agent has the ability to induce mutations or so called indicator effects which are mechanistically associated with the formation of mutations (for example, induction of DNA modifications, DNA repair, or recombination) [2].

Environmental contaminants can affect the genetic makeup of populations in three ways: via mutations, genetic drift, and genetic adaptation [2]. Some of these pollutants are carcinogenic and mutagenic with the capacity to affect both the structural integrity of DNA and the fidelity of its biological expressions [3].

Genetic toxicology is an area of science in which the interaction of DNA-damaging agents with the cell's genetic material is studied in relation to subsequent effects on the health of the organism [1]. Ecogenotoxicology (genetic ecotoxicology) is an approach that applies the principles and techniques of genetic toxicology to assess the potential effects of environmental pollution in the form of genotoxic agents on the health of the ecosystem [1]. Genetic hazard assessment, thus, deals with changes in genetic material of organisms, either human or other natural origin (OSPAR, 2002). Several reviews demonstrate the presence and potency of genotoxins from a broad range of industrial and municipal effluents [4-6] as cited by OSPAR [7]. There is a close association of DNA damage, mutation, and induction of various types of cancer [7]. Fish serves as useful genetic model for the evaluation of pollution in aquatic ecosystems $[8,9]$. Fish species from contaminated areas initiated studies in the aquatic environment [10-12], and evidence is growing that environmental mutagens can reduce the reproductive success of populations [13]. Different genotoxicity tests and their applications to environmental monitoring and assessment have been variously reported in fish [14-23]. Some of the methods are based on OECD and EC guidelines used for chemical risk assessment [7].

\section{Genetic Mechanism of Changes in Ecogenotoxicology}

One of the crucial questions in the field of environmental genotoxicology is how the potential hazards and risk of genotoxic substances should be evaluated [24]. To answer this question a distinction has to be made between the different pathways along which a chemical is able to affect the genetic structure of an organism and the subsequent effects this may have for the populations in the field [24].

It is difficult to demonstrate the effect of environmental stressors, including genotoxicants, at the ecosystem level, where population and communities are studied because the responses observed are latent and so far removed from the initial event(s) of exposure that causality is often almost impossible to establish [1]. A way to solve this problem is to view ecosystem as dynamic interactions of living and inert matter where the living material acclimates and adapts to environmental changes. These processes are physiological and have genetic basis, therefore, understanding changes at the genetic level (DNA) should help define the more complex changes at the ecosystem level [1].

The genetic apparatus of an organism can interact with

*Corresponding author: Akpoilih BU, Department of Animal Science and Fisheries, University of Port Harcourt, Nigeria, Tel: 23408134381645; E-mail: uzeziu2@yahoo.co.uk

Received November 05, 2012; Accepted December 28, 2012; Published December 31, 2012

Citation: Akpoilih BU (2013) Fish Ecogenotoxicology: An Emerging Science, an Emerging Tool for Environmental Monitoring and Risk Assessment. J Environ Anal Toxicol 3:165. doi:10.4172/2161-0525.1000165

Copyright: () 2013 Akpoilih BU. This is an open-access article distributed under the terms of the Creative Commons Attribution License, which permits unrestricted use, distribution, and reproduction in any medium, provided the original author and source are credited. 
genotoxicants in a variety of ways and an understanding of the cellular mechanisms involved in these interactions provide the researcher the opportunity to predict and possibly prevent contaminant-induced genetic damage in exposed populations [1]. Genotoxicants can alter the structural integrity of the DNA, cause mutations and subsequent heritable effects or even cause non-mutagenic effects. Conversely, the organism may perceive the genotoxicant and attempt to eliminate the agent or repair changes to the DNA [25]. If the genotoxic agent directly attacks the DNA, the organism may perceive this damage and attempt repair [26]. The flow of genotoxic stress within a somatic cell [27] and the mechanisms involved have been reviewed [28,29]. Cellular processes regulating these events in the DNA are very complex and for which there are little understanding [1]. These processes are affected differently in different species and may depend upon, for example, the type or class of genotoxic agent and the reactivity of its metabolites, capacity of the cell to recognize and suppress the multiplication of cells with aberrant properties [29]. Effects expressed in somatic cells can be detrimental to the exposed individual, whereas, mutational events may affect subsequent generations [1]. Extrapolation of effects on somatic cells to germ cell level of organization is difficult due to the inherent difference in sensitivity of these type of cells to genotoxicants [30]. Furthermore, establishing a causal relationship between a genotoxic agent in the environment and a deleterious effect in subsequent generations of that organism is also highly unlikely because individuals carrying harmful mutations are eliminated from the population due to a strong selection against less fit and less well-adapted individuals [31].

\section{Role of Fish in Ecogenotoxicology}

Genotoxins are chemicals are responsible for DNA damage in variety of aquatic organisms and fishes in particular causing malignancies, reduced growth, and abnormal development, reduced survival of embryos, larvae, and adults, ultimately affecting the economy of fish production significantly. Genotoxicity not only reduces the "fitness" in wild fish populations, but also pose risk to human health via food chain [32].

Although, technical advancements have been made in some mammalian species and also in fruit flies, the desired progress has not been achieved towards evaluation of potential hazards and risks from genotoxic pollutants in fish species [32].

The selection of fish as a model in ecogenotoxicological studies could be made necessary since fish is a very sensitive biomarker indicator of water quality and can highlight the potential danger of new chemicals introduced in the aquatic environment and also respond to toxicants in a manner similar to higher vertebrates [33]. Fish serves as useful genetic model for the evaluation of pollution in aquatic environment $[8,9]$. Current awareness of the potential hazards of pollutants in the aquatic environment has stimulated much interest in the use of fish as indicators for monitoring carcinogens, teratogens, clastogens, and mutagens [34]. This is because aquatic environment serves as convenient repositories for man's biological and technological wastes [35]. Fish play different roles in the tropic web such as undergoing bioaccumulation of environmental pollutants and biotransformation of xenobiotics through cytochrome p450dependent oxidative metabolism; besides they respond to mutagens at low concentrations [36]. Fish cells retain important traits of fish; for example, poikilothermic behaviour, unique xenobiotic metabolism, and low rate of repair mechanism; they have been shown to be more sensitive for the induction of genetic damage [32]. DNA repair has been shown to be slower in fishes than mammals $[37,38]$. Therefore, they can be used as sentinel organism for biomonitoring studies. Fish have severally been used in several eukaryotic genotoxicity and mutagenicity tests, which include its use in Comet assay [39], DNA repair synthesis [23], Chromosomal aberration test [40,41], Micronucleus assay [42-44], and Sister chromatid exchange test $[45,46]$. Therefore, efforts should be made to utilize assays for detecting genotoxicity caused by aquatic pollutants in fishes at DNA level. This will help in formulating longterm strategies for fish conservation programme besides estimating safe Level of pollutants in water [32].

\section{Role of Ecogenotoxicology in Environmental Monitor- ing}

Contrary to human toxicology studies which focus on the fate of the individual, ecogenotoxicology evaluates the consequences of genotoxicants for population sizes and structure. Investigations showing high prevalence of hepatic tumors in different fish species from contaminated areas initiated studies in the aquatic environment [1012]. Several examples of neoplasms in fish due to waste water effluents have been described $[47,48]$. Exposure to DNA-damaging agents may result in the formation of carcinogen-DNA adducts, which, as possible indicators for carcinogens, have been detected in mussels [49], and fish from contaminated sites [50-53]. Thus, detection of adducts provide a way of documenting exposure. This approach was used to examine DNA from beluga whales in St Lawrence estuary, Quebec, Canada, to determine whether exposure to benzo (a) pyrene $(\mathrm{BaP})$, a potent environmental carcinogen and the suspected etiological agent for the high incidence of cancer in these animals had occurred [54].

Early in 1987 [1], the detection of excessive strand breakage in the DNA of several aquatic species was implemented as a biomonitor for environmental genotoxicity as part of the Biological and Monitoring and Abatement Program for the US Department of Energy (USDOE) Reservation in Oak Ridge, Tennessee. This approach was effectively used in studies with two species of turtles, the snapping turtle (Chelydra serpentine) and Pond slider (Trachemis scripta) [55], using the Alkaline DNA unwinding assay [56]. Similarly, analysis of strand breaks in Sun fish [1], using the DNA alkaline unwinding assay [56], has been employed as a biological marker for environmental genotoxicity as part of the Biological Monitoring and Abatement Program at East Fork Popler Creek [56]. This creek is the receiving stream for industrial effluent from the USDOE reservation in Oak Ridge, Tennessee, USA. Water and sediments downstream contain metal, organic chemicals and radionuclides discharged over many years of operations [56]. The erythrocyte micronucleus test has been used with different fish species [34] and other marine shellfish to monitor aquatic pollutants displaying mutagenic features in developed countries [42-44]. Current awareness of the potential hazards of pollutants in the aquatic environment has stimulated much interest in the use of fish as indicators for monitoring carcinogens, teratogens, clastogens and mutagens [34]. This is because aquatic environment serves as convenient repositories for man's biological and technological wastes [35]. Aquatic animals have often been used as assay to evaluate surface water [57,58]. Substances displaying mutagenic, teratogenic and carcinogenic potentials are easily evaluated because of high sensitivity of these organisms to these pollutants at low concentrations $[59,60]$. Obiakor et al. [61,62], have demonstrated the use of Synodontis clarias and Tilapia nilotica from freshwater of the Anambra River, Nigeria, in ecogenotoxicology studies using the micronucleus test and validating them as index of cytogenetic damage, monitoring of aquatic genotoxicants and other sublethal concentrations of chemical pollutants. 
Ideally, genetic ecotoxicology will begin to address such outcomes of exposure to environmental genotoxicants as disease, decreased reproductive success, and altered genotypic diversity [1], using endpoints such as frequencies of gametes loss due to cell death, embryo mortality caused by lethal mutations, abnormal development, cancer, and mutation frequencies affecting the gene pool of exposed populations [13]. But, up till now only endpoints like gamete loss or teratogenic effects as well as cancer incidences can be measured [7]. Effects for exposed populations might be estimated in case where these populations are ecologically characterized, but knowledge about consequences of genotoxic exposure on the gene pool of exposed species is still scarce [63], however, the principles underlying research of effects of genotoxicants on genetic diversity are not new as there are newer approaches to describe genetic effects of contaminants on the population level $[24,64]$, which focus on the genetic diversity, examining the current status and history of population by molecular genetics technique [1]. But these effects are not necessarily caused by mutagenicity; they depend also on chronic effects and population size [65].

In a heterozygous population, there are likely to be certain genotypes that are more sensitive to genotoxic exposure than others. This is so if the population is heterozygous at loci that are both critical to fitness and susceptible to toxicant-induced structural alterations [1]. Genotoxic exposure can act as a selective force by eliminating sensitive genotypes, or reducing the number of offspring that they contribute to the next generation. The result can be a reduction in the total genetic variation within the population or a shift in genotypic frequencies [1].

\section{Role of Ecogenotoxicology in Environmental Risk Assessment}

Genetic hazard assessment investigates changes in genetic material of organisms, either human or other natural origin [7]. A review of ecogenotoxicology in environmental risk assessment has been presented by Roex et al. [24]. Regulatory authorities worldwide require data on the genotoxic potentials of new drugs and chemicals [66], through genotoxicity testing for hazard identification with respect to DNA damage [67], and biological information indicative of toxicity, which can be interpreted and/ or extended to the assessment of health risk to humans [68] and the environment [24]. Today, in the pharmaceutical industry, it is not possible to register a new drug without providing information on its mutagenicity [69]. In ecogenotoxicology, possible effects of mutagenic/genotoxic substances on populations and ecosystems are investigated. Mutagenicity testing of genotoxic substances has been performed with all types of organisms [7].

In risk assessment of chemicals, a first screening for mutagenicity takes place in a battery of three in vitro (in situ) genotoxicity test, after which an in vitro carcinogenicity test is carried out based on a position result in the in vitro test [70], the result of which is extrapolated to carcinogenic risk for humans by calculating a lifetime exposure level corresponding to a unit risk of $10^{-6}$, which is accomplished by linear extrapolation from lowest effective dose to 0 [24]. Ecological risk assessment concerns a wider range of species instead of a single one like in human genotoxicology, and has to deal with the protection of populations instead of individuals [30,71].

Test animals that are used in carcinogenicity studies for risk assessment are mostly mice, rats, or hamster for which extrapolation to human situations makes them suitable models [24]. However, for extrapolation to ecosystem, carcinogenicity test batteries with more representative species such as fish, daphnia, and algae used in ecological risk assessment procedures are appropriate as these models, particularly fish, have been used severally in ecological risk assessment studies [72,73], demonstrating the ecogenotoxicological significance of these models.

\section{Applications of Ecogenotoxicological Methods in Monitoring and Risk Assessment}

For monitoring purpose, higher organisms (eukaryotes) are exposed to environmental compartment "in situ" or in laboratory test "in vivo" [7]. Some of the methods applied to environmental samples are based on corresponding OECD and EC guidelines used for chemical risk assessment, but others have not yet been standardized [7]. The bacterial Ames test, Umu-C assay [74], and SOS chromo assay $[75,76]$, have been applied predominantly to waste water samples. Tests with eukaryotes cells or organisms are relevant for ecological risk assessment-plants, amphibians, fish, permanent cell lines such as Chinese hamster lung cells (V79) [15,77-79], Chinese hamster ovary cells (CHO) [80-82], and Chinese hamster lung cells (CHL) [83], marine and freshwater mussels-have been used as test organisms [7]. An overview of some genotoxicity test methods and their application to monitoring and assessment is given below.

\section{Comet assay}

The comet assay has been developed from the method of Rydbert and Johansen, who were the first to perform a quantitation of DNA damage in single cells. Later on, Ostling and Johanson, improved the assay by developing an electrophoretic microgel technique under neutral conditions and stained the DNA with acridine orange. The more versatile alkaline method of the comet assay was developed by Singh et al. [84], which was developed to measure low levels of strand breaks with high sensitivity. In general, cells are mixed with low-melting agarose placed on microscope slides and lysed by an alkaline buffer with ionic detergents. The liberated DNA is resolved in an electrophoresis chamber, stained and evaluated by florescence microscopy. Cells with increased DNA damage display increased migration from the nuclear region towards the anode [84]. The resulting comet like structure is quantified by measuring the length of the tail and/ or tail moment (the intensity of the migrated DNA multiplied by the respective tail length with respect to the DNA). A review of th eaplicability of the comet assay in environmental monitoring has been provided by Mitchelmore and Chipman [22] and has been applied to a broad range of aquatic organisms, including fish [85-88].

\section{DNA alkaline unwinding assay}

The level of DNA strand breaks with respect to the total DNA can be determined by following a time-dependent alkaline unwinding assay. Unwinding of DNA takes place at single stranded breaks, hence the amount of double stranded DNA remaining after a given period of alkaline exposure will be inversely proportional to the number of strand breaks; this ratio is expressed in form of $F$ values, which measures the relative double strandedness of a particular DNA [56]. In situ investigations for the detection of genotoxic potential in selected surface water with the DNA alkaline unwinding assay have been reported using fish cells, early life stages of fish, crustaceae, and mussels [55,89]. Everaarts and Sarkar [90], studied DNA damage in sea stars (Asterias rubens) in order to assess the state of pollution of the North Sea. 


\section{DNA repair synthesis (UDS-assay)}

The unscheduled DNA synthesis assays measures the incorporation of radioactively labelled nucleosides (usually tritium-labelled thymidine) in cells that are not undergoing scheduled DNA synthesis. The DNA repair synthesis UDS test has been applied using primary hepatocytes from fish to assess genotoxicity in surface water [23].

\section{Chromosome aberration test}

Chromosome mutation is a macrodamage of chromosome [7]. Chromosome aberration includes structural aberrations such as fragments, intercalations, and numeral aberrations resulting from either direct DNA breakage or inhibition of DNA synthesis [91]. Cytogenic effects can be studied either in whole animals (in vivo) or in cells grown in culture (in vitro) [91]. Generally, the cell culture is exposed to the test substance and then afterwards treated with a metaphase-arresting Colcimide [7] or Colchicine [91]. Following suitable staining the metaphase cells are analysed microscopically for the presence of aberration.

Although, cytogenic studies were initiated on agnathan (Myxine gluttinosa), fish cytogenetics got real momentum with the work of as cited by Nagpure et al. [91]. Since then, the test has been carried or evaluated in several fish species $[41,40,92,93]$.

\section{Micronucleus assay}

The micronuclei are chromosome fragments or whole chromosomes that were not incorporated in the daughter cell nuclei and appear in the cytoplasm [94]. The micronucleus test is a simple and sensitive assay for "in vivo" evaluation of genotoxic properties of various agents. Chromosomes in fish cells are usually of small size and occur in large numbers; therefore, it can be easily applied to fish or other aquatic organisms sine small and large number of chromosome do not affect the micronucleus assay [33].

Environmental biomonitoring with micronucleus assays usually has been performed "in vivo" by exposure of relevant aquatic organisms for several days followed by microscopic analysis of erythrocytes, gill cells. But permanent fish cell lines (RTG-2) have also been used "in vitro" $[95,96]$. "In vivo" studies with fish have severally been used and reported for genotoxicity with the micronucleus $[34,97,98]$.

\section{Sister chromatid exchange (SCE) test}

The sister chromatid exchange test detects reciprocal exchanges of DNA segments between two sister chromatids of a duplicating chromosome [99]. Although little is known about the molecular basis, the SCE frequency is elevated under the influence of mutagenic agents and therefore serves as a model for genotoxicity [7]. For genotoxicity assessment in environmental samples SCE assays have been performed with mussels [100,101], fish cells [45,46,102].

\section{Recent developments}

In the field of genotoxicological evaluation of environmental samples, recent advancement has been achieved [7]. Amanuma established a transgenic zebrafish for the detection of mutagens; it carries plasmids that contain the rpSL gene of Escherichia coli as a mutational target gene [72]. Winn et al. [103] prepared a transgenic fish that carries multiple copies of a bacteriophage lambda vector that harbours the cII gene as a mutational target, a technique originally developed for lambda transgenic rodents. The p53 tumor suppressor gene, which is known to be implicated in cancer development, has been investigated as a possible biomarker for genotoxin in fish cells $[11,104,105]$. The amplification of DNA by polymerase chain reaction technique enabled the detection of mutations at specific sites and the development of electrochemical DNA based biosensors [106,107].

\section{Limitations in ecogenotoxicology}

Increased mutations rates due to environmental pollution might negatively affect populations [7]. This is still controversially debated in the scientific community $[13,30]$, but evidence is growing that environmental mutagens can reduce reproductive success of populations [7]. Even though an increasing number of studies involving ecogenotoxicity are available $[20,63,108,109]$, the identification of clear cause-effect relations is increasingly complicated, the higher the level of biological organization. For instance, For example, Shugart and Theodorakis $[110,111]$, examined a series of retention ponds heavily contaminated with radionuclides, but which support a resident population of mosquitofish (Gambusia affinis) for the past 20 years. They reported that there was an inverse correlation between DNA strand breakage and fecundity of fish from the contaminated ponds [1]. This has implications for higher-order ecological effects, as well as for contaminant-induced selection of resistant phenotypes. Current investigations have provided evidence that genetic diversity is increased in the population of fish occupying the radionuclide-contaminated sites relative to reference sites [1]. These findings are supported both by allozyme analysis - through determination of average heterozygosity and percent polymorphisms, and by the RAPD (randomly amplified polymorphic DNA) technique-by determining average similarities of banding patterns between individuals within populations. In addition it has been found that certain banding patterns are more prevalent in the contaminated sites than in the reference sites. Individuals which display these banding patterns at one of the contaminated sites have a higher fecundity and lower degree of strand breakage than do individuals with the less common banding patterns. This type of pattern is also observed with allozyme analysis-heterozygotes, especially at the nucleoside phosphorylase locus, are more common in the contaminated sites. Within the contaminated sites, heterozygotes have a higher fecundity and lower degree of strand breakage than do homozygotes. Long term laboratory exposures where environmental variables can be more rigidly controlled are underway in an effort to establish relationships between genotype, DNA strand breakage, and fecundity.

Ideally, genetic ecotoxicology will begin to address such outcomes of exposure to environmental genotoxicants as disease, decreased reproductive success, and altered genotypic diversity [1], using endpoints such as frequencies of gametes loss due to cell death, embryo mortality caused by lethal mutations, abnormal development, cancer, and mutation frequencies affecting the gene pool of exposed populations [13]. But, up till now only endpoints like gamete loss or teratogenic effects as well as cancer incidences can be measured [7]. Effects for exposed populations might be estimated in case where these populations are ecologically characterized, but knowledge about consequences of genotoxic exposure on the gene pool of exposed species is still scarce $[7,63]$.

Majority of the currently used genotoxicity testing assays for regulatory toxicity testing were developed in the 1970's [66]. In most of the cases, the site and mechanism by which genotoxicity is produced by the compound under the study is not known [66]. It may happen that the target site of toxic action may not be the same target site of toxic action of a new chemical entity (NCE) [66]. Also, in subchronic and chronic toxicity testing, several pertinent parameters or endpoints 
can be detected to determine the toxicity, but the same is rarely true for genotoxicity tests [68]. Moreover, for certain categories of chemicals [66], which need critical experimental evaluation, there are no details with regards to the choice of specific test system and test protocols [112]. Most guidelines are devoid of recommendations for compounds, which are genotoxic, but seem to act by non-DNA target [113]. There are also no specific recommendations on the threshold of different genotoxic and tumorogenic compounds and their organ-specific effects when they are intended to use therapeutically [114]. A single test system cannot be designed for universal detection of the relevant genotoxic substances; testing requirements depend on the nature and category of chemical substances [66]. In addition, there is no validated test system for detecting induced genome mutation (aneuploidy) in germ cells [115].

\section{Conclusion}

It is now clear that environmental genotoxicology holds the key to early detection and monitoring of pollution in aquatic environments, particularly when fish species are the test organisms. Fish serves as useful genetic model for the evaluation of pollution in aquatic ecosystems [8,9]. Fish species from contaminated areas initiated studies in the aquatic environment [10-12] and evidence is growing that environmental mutagens can reduce the reproductive success of populations [13]. Different genotoxicity tests and their applications to environmental monitoring and assessment have been variously reported in fish [14-23]. Fish cells retain important traits of fish; for example, poikilothermic behaviour, unique xenobiotic metabolism, and low rate of repair mechanism [32]. DNA repair has been shown to be slower in fishes than mammals [37,38]. Therefore, they can be used as sentinel organism for biomonitoring studies. Fish have severally been used in several eukaryotic genotoxicity and mutagenicity tests, which include its use in Comet assay [39], DNA repair synthesis [23], Chromosomal aberration test [40,41], Micronucleus assay [42-44], and Sister chromatid exchange test $[45,46]$. Therefore, efforts should be made to utilize assays for detecting genotoxicity caused by aquatic pollutants in fishes at DNA level. This will help in formulating longterm strategies for fish conservation programme besides estimating safe Level of pollutants in water [32]. Recent advancement has been made in the field of ecogenotoxicology [11,72,103-105], which use has also been recommended for in genotoxicity testing of new chemical entity (NCE) and pharmaceuticals by the International Conference on Harmonization (ICH) [66]. However, several drawbacks have hindered the effective use of genotoxicity tests in ecogenotoxicology $[7,13,30,66]$. Global efforts should be intensified and harmonized to solve some of these problems such as validating test systems to detect aneuploidy by anticentromere antibody [116], identification of apoptosis [117], use of fluorescent in situ hybridization (FISH) to visualize translocation of chromosomes [118,119], unscheduled DNA synthesis (UDS) [120], and cell transformation assay [121] in fish. All the foregoing genotoxic screening methods, except apoptosis and unscheduled DNA synthesis (UDS), which have been used in fish [23,122], have only been reported in man. Appropriate screening tests should also be validated for investigating consequences of genotoxins, not only on populations, but also on gene pool. These tests will increase both the sensitivity and specificity of existing test protocols [66].

\section{Acknowledgement}

Special thanks to God almighty for the will and strength in writing this paper and to authors whose contributions in the field of environmental ecogenotoxicology helped in the completion and whose names were conspicuously cited.

\section{References}

1. Shugart L, Theodorakis C (1998) New trends in biological monitoring application of biomarkers to genetic ecotoxicology. Biotherapy 11: 119-127.

2. Belfiore NM, Anderson SL (1998) Genetic patterns as a tool for monitoring and assessment of environmental aspects: the example of genetic toxicology. Environmental monitoring and assessment 51: 465-479.

3. Wogan GN, Gorelick NJ (1985) Chemical and biochemical dosimetry of exposure to genotoxic chemicals. Environ Health Perspect 62: 5-18.

4. De Raat WK, Vink GJ, Hanstveit AO (1990) The significance of mutagenicity as a criterion in ecogenotoxicological evaluations. 249-269. In: Waters, M.D Daniels, F.B, Lewtas, J, Moore, M.M, Nesnow, S (eds). Genetic toxicology of complex mixtures. Plenum Press, New York, USA

5. White PA, Rasmussen JB, Blaise C (1996) Comparing the presence, potency, and potential hazard of genotoxins extracted from a broad range of industria effluents. Environ Mol Mutagen 27: 116-139.

6. Claxton LD, Houk VS, Hughes TJ (1998) Genotoxicity of industrial wastes and effluents. Mutat Res 410: 237-243.

7. Gartiser S, Hafner C, Hercher C, Kronenberger-Schäfer K, Paschke A (2010) Whole effluent assessment of industrial wastewater for determination of BAT compliance. Part 2: metal surface treatment industry. Environ Sci Pollut Res Int 17: 1149-1157.

8. Mitchell SH, Kennedy S (1992) Tissue concentrations of organochlorine compounds in common seals from the coast of Northern Ireland. Sci Total Environ 115: 163-177.

9. Park E, Lee J, Etoh H (1993) Fish Cell line (ULF-23HU) Derived from the Fin of the Central Mudminnow (Umbra limi): Suitable Characteristics for Clastogenicity Assay. In Vitro Cell Dev Biol 25: 987-994.

10. Murchelano RA, Wolke RE (1991) Neoplasms and nonneoplastic liver lesions in winter flounder, Pseudopleuronectes americanus, from Boston Harbor Massachusetts. Environ Health Perspect 90: 17-26.

11. Mc Mahon G (1994) The genetics of human cancer: implications for ecogenotoxicology. Environ Health Perspec 102: 75-80.

12. Moore MJ, Myers MS (1994) Pathobiology of chemical-associated neoplasia in fish. Pages 327-386. In: Malins, D.C and Ostrader, G.K (eds). Aquatic Toxicology. Molecular, Biochemical and Cellular Perspectives. Lewis Publishers, Boca Raton, Ann Arbor, London, Tokyo.

13. Anderson SL, Wild GC (1994) Linking genotoxic responses to reproductive success in ecogenotoxicology. Environ Health Perspec 102: 9-12.

14. Hartmann A, Golet EM, Gartiser S, Alder AC, Koller T, et al. (1999) Primary DNA damage but not mutagenicity correlates with ciprofloxacin concentrations in German hospital waste waters. Arch Environ Contam Toxicol 36: 115-119.

15. Gartiser S, Stiene G, Hartmann A, Zipperle J (2001) Use of disinfectants in hospitals cause of ecotoxic and genotoxic effects in Krankakenhausabwasser. Vom Wasser 96: 71-88.

16. White PA, Rasmussen JB, Blaise C (1998a) Genotoxic substances in the St. Lawrence system I: Industrial genotoxins sorbed to particulate matter in the St. Lawrence, St. Maurice and Sagueny Rivers, Canada. Environ Tox Chem 17: $286-303$.

17. White PA, Rasmussen JB, Blaise C (1998b) Genotoxic substances in the St. Lawrence system II: extracts of fish and macroinvertebrates from the St. Lawrence and Sagueny Rivers, Canada. Environ Tox Chem 17: 304-306.

18. Helma C, Mersch-Sundermann V, Houk SV, Glasbrenner U, Klein C, et al. (1996) Comparative evaluations of four bacterial assays for the detection of genotoxic effects in the dissolved water phases of aqueous matrices. Environ Sci Technol 30: 897-907.

19. Vargas VM, Migliavacca SB, de Melo AC, Horn RC, Guidobono RR, et al. (2001) Genotoxicity assessment in aquatic environments under the influence of heavy metals and organic contaminants. Mutat Res 490: 141-158.

20. Hose JE, Brown ED (1998) Field applications of the piscine anaphase aberration test: lessons from the Exxon Valdez oil spill. Mutat Res 399: 167-178.

21. Stahl RG Jr (1991) The genetic toxicology of organic compounds in natura waters and wastewaters. Ecotoxicol Environ Saf 22: 94-125. 
Citation: Akpoilih BU (2013) Fish Ecogenotoxicology: An Emerging Science, an Emerging Tool for Environmental Monitoring and Risk Assessment. J Environ Anal Toxicol 3:165. doi:10.4172/2161-0525.1000165

22. Mitchelmore CL, Chipman JK (1998) DNA strand breakage in aquatic organisms and the potential value of the comet assay in environmental monitoring. Muta Res 399: 135-147.

23. Grummt T (2000b) DNA repair synthesis (Unscheduled DNA Synthesis) as a parameter for the assessment of genotoxicity in surface waters combined with biologic and cell biologic methods. In: Grummt, T (ed). 217

24. Roex EWM, Traas TP, Slooff W (2001) Ecotoxicological hazard assessment of genotoxic substances .Research For Man and Environment (RIVM) Report.

25. Guengerich FP (1993) Cytochrome P450 enzymes. Am Sci 81: 440-447.

26. Shugart LR, Bicham J, Jackim G, McMahon G, Ridley W, et al. (1992) DNA alterations. In: Huggert, R, Kimerle, R, Mehrle, P, Bergman, H (eds). Biomarkers: Biochemical, Physiological, and Histological Markers of Anthropogenic Stress. Boca Raton, FL: Lewis Publishers Inc, 127-153.

27. Brusick D (1980) Principles of genetic toxicology. New York: Plenum Press.

28. Thilly WG, Call KM (1986) Genetic toxicology. In: Klaassen DD, Amdor MO Doull J (eds). Third edition of Casarett and Doull's Toxicology. New York: Macmillan Publishing Co. 174-179.

29. Clive D (1987) Genetic Toxicology: from theory to practice. Clin Res Drug Development 1: 11-41.

30. Würgler FE, Kramers PG (1992) Environmental effects of genotoxins (ecogenotoxicology). Mutagenesis 7: 321-327.

31. Bickham JW, Smolen MJ (1994) Somatic and heritable effects of environmenta genotoxins and the emergence of evolutionary toxicology. Environ Health Perspect 12: 25-28

32. Kapour D, Nagpure NS (2005) Training on genotoxic assays in fishes. Kapour D, Nagpure NS (eds). National Bureau of Fish Genetic Resources. Dilknsha, Telibagh, India. 68

33. al-Sabti K, Metcalfe CD (1995) Fish micronuclei for assessing genotoxicity in water. Mutat Res 343: 121-135

34. Obiakor MO, Okonkwo JC, Nnabude PC, Ezeonyejiaku CD (2012) Ecogenotoxicology: Micronucleus Assay in Fish Erythrocytes as In situ Aquatic Pollution Biomarker: a Review. J Anim Sci Adv 2: 123-133.

35. Cajaraville MP, Bebianno MJ, Blasco J, Porte C, Sarasquete C, et al. (2000) The use of biomarkers to assess the impact of pollution in coastal environments of the Iberian Peninsula: a practical approach. Sci Total Environ 247: 295-311.

36. Helbling A, Haydel R Jr, McCants ML, Musmand JJ, El-Dahr J, et al. (1999) Fish allergy: is cross-reactivity among fish species relevant? Double-blind placebo-controlled food challenge studies of fish allergic adults. Ann Allergy Asthma Immunol 83: 517-523.

37. Walton DG, Acton AB, Stich HF (1984) DNA repair synthesis following exposure to chemical mutagens in primary liver, stomach, and intestinal cells isolated from rainbow trout. Cancer Res 44: 1120-1121.

38. Espina NG, Wesis P (1995) DNA repair in fish from polluted estuaries. Mar Environ Res 39: 309-312.

39. Sumathi M, Kalaiselvi K, Palanivel M, Rajaguru P (2001) Genotoxicity of textile dye effluent on fish (Cyprinus carpio) measured using the comet assay. Bull Environ Contam Toxicol 66: 407-414.

40. Al-Sabti K (1985) Frequency of chromosomal aberrations in the rainbow trout (Salmo gairdini Rich) exposed to live pollutants. J Fish Biol 26: 13-19.

41. Rishi KK, Grewal S (1995) Chromosome aberration test for the insecticide, dichlorvos, on fish chromosomes. Mutat Res 344: 1-4.

42. De Flora S, Viganò L, D’Agostini F, Camoirano A, Bagnasco M, et al. (1993) Multiple genotoxicity biomarkers in fish exposed in situ to polluted river water. Mutat Res 319: 167-177.

43. Saotome K, Hayashi M (2003) Application of a sea urchin micronucleus assay to monitoring aquatic pollution: influence of sample osmolality. Mutagenesis 18: 73-76

44. Pantaleao SM, Alcantara AV, Alves JPH, Spano MA (2006) The Piscine Micronucleus Test to Assess the Impact of Pollution on the Japaratuba River in Brazil. Environ Mutagen 47: 219-224.

45. Kligerman AD, Bishop WE, Valentine LC (1984) Use of the mudminnow, Umbra $\mathrm{sp}$., in an in vivo sister chromatid exchange test. Natl Cancer Inst Monogr 65: 111-118.
46. Sahoo PK, Barat A, Ponniah AG (1998) In vitro sister chromatid differentiation and base line sister chromatid exchanges in Channa punctatus. Indian I Exp Biol 36: 1041-1043.

47. Metcalfe CD, Sonstegard RA (1985) Oil refinery effluents: evidence of cocarcinogenic activity in the trout embryo microinjection assay. J Natl Cance Inst 75: 1091-1097.

48. Kimura I, Kinae N, Kumai H, Yamashita M, Nakamura G, et al. (1989) Environment: perculiar pigment cell neoplasm in fish. J Invest Dermatol 5: 248 254.

49. Harvey JS, Lyons BP, Waldock M, Parry JM (1997) The application of the 32P-postlabelling assay to aquatic biomonitoring. Mutat Res 378: 77-88.

50. Dunn BP (1991) Carcinogen adducts as an indicator for the public health risks of consuming carcinogen-exposed fish and shellfish. Environ Health Perspect 90: $111-116$

51. Weisburger JH, Williams GM (1991) Critical effective methods to detect genotoxic carcinogens and neoplasm-promoting agents. Environ Health Perspect 90: 121-126.

52. el Adlouni C, Tremblay J, Walsh P, Lagueux J, Bureau J, et al. (1995) Comparative study of DNA adducts levels in white sucker fish (Catostomus commersoni) from the basin of the St. Lawrence River (Canada). Mol Cell Biochem 148: 133-138.

53. Ericson G, Larsson A (2000) DNA adducts in perch (Perca fluviatilis) living in coastal water polluted with bleached pulp mill effluents. Ecotoxicol Environ Sa 46: 167-173.

54. Martineau D, Lagace A, Beland P, Higgins R, Armstrong D, et al. (1988) Pathology of stranded beluga whales (Delphinapterus leucas) from the St Lawrence Estuary, Quebec, Canada. J Comp Path 98: 287-311.

55. Meyer-Schone L, Shugart LR, Beauchamp JJ, Walton BT (1993) Comparison of two freshwater turtle species as monitors of radionuclide and chemical contamination: DNA damage and residue analysis. Environ Tox Chem 12: 1487-1496.

56. Shugart LR (1990) DNA damage as an indicator of pollutant-induced genotoxicity. In: Landis WG, van der Schalie WH (eds). 13th Symposium on Aquatic Toxicology and Risk Assessment: Sublethal Indicators of Toxic Stress. Philadelphia PA: ASTM. Pp 348-355.

57. Brungs WA, McCormick JH, Neiheisel TW, Spehar RL, Stephan CE, et al. (1977) Effects of pollution on freshwater fish. J Water Pollut Control Fed 49 1425-1493.

58. Carins J, Dickson KL, Vestlake GF (1975) Biological Monitoring of Water and Effluent Quality. ASTM Publ 607 Philadelphia.

59. Koeman JH, Poel CL, Slooff W (1977) Continuous Biomonitoring Systems fo Detection of Toxic Levels of Water. In: Hutzinger O (Eds.), Aquatic Pollutants, Pergamon, Oxford 339-348.

60. Poele CL, Strik JJT (1975) Sublethal Effects of Toxic Chemicals on Aquatic Animals, proceedings of the Swedish-Netherlands Symposium, Wageningen, The Netherlands.

61. Okonkwo JC, Obiakor MO, Nnabude PC (2010a) Micronucleus Profile: An Index of Chromosomal Aberrations in Freshwater Fish (Synodontis clarias and Tilapia nilotica). Online J Anim Feed Res 1: 40-45.

62. Obiakor MO, Ezeonyejiaku CD, Ezenwelu CO, Ugochukwu GC (2010c) Aquatic Genetic Biomarkers of Exposure and Effect in Catfish (Clarias gariepinus Burchell, 1822) American-Eurasian Journal of Toxicological Sciences 2: 196 202

63. Theodorakis CW, Bickham JW, Elbl T, Shugart LR Chesser RK (1998) Genetics of radionuclide-contaminated mosquitofish populations and homology between Gambusia affinis and G holbrooki. Environ Toxicol Chem 17: 1992 1998.

64. Anderson S, Sadinski W, Shugart L, Brussard P, Depledge M, et al. (1994) Genetic and molecular ecogenotoxicology: a research framework. Environ Health Perspec 102: 3-8.

65. Bickham JW, Sandhu S, Hebert PD, Chikhi L, Athwal R (2000) Effects of chemical contaminants on genetic diversity in natural populations: implications for biomonitoring and ecotoxicology. Mutat Res 463: 33-51.

66. Jena GB, Kaul CL, Ramarao P (2001) Genotoxicity testing, a requirement for drug discovery and development: impact of $\mathrm{ICH}$ guidelines. Indian J Pharmaco 34: $86-99$ 
Citation: Akpoilih BU (2013) Fish Ecogenotoxicology: An Emerging Science, an Emerging Tool for Environmental Monitoring and Risk Assessment. J Environ Anal Toxicol 3:165. doi:10.4172/2161-0525.1000165

67. Madle S, Korte A, Ball R (1987) Experience with mutagenicity testing of new drugs: viewpoint of a regulatory agency. Mutat Res 182: 187-192.

68. Nath J, Krishna G (1998) Safety screening of drugs in cancer therapy. Acta Haematol 99: 138-147.

69. Cartwright AC, Mathews BR (1994) International pharmaceutical product registration: Aspects of quality, safety and efficacy. New York: Ellis Horwood Limited.

70. Kramers PG, Knaap AG, van der Heijden CA, Taalman RD, Mohn GR (1991) Role of genotoxicity assays in the regulation of chemicals in The Netherlands: considerations and experiences. Mutagenesis 6: 487-493.

71. de Jong BW, Bakker Schut TC, Wolffenbuttel KP, Nijman JM, Kok DJ, et al. (2002) Identification of bladder wall layers by Raman spectroscopy. J Urol 168 1771-1778.

72. Amanuma K, Takeda H, Amanuma H, Aoki $\mathrm{Y}$ (2000) Transgenic zebrafish for detecting mutations caused by compounds in aquatic environments. Nat Biotechnol 18: 62-65

73. Burhart JG (2000) Fishing for mutations. Nature Biotechnology 18: 21-22.

74. Oda Y, Nakamura S, Oki I, Kato T, Shinagawa H (1985) Evaluation of the new system (umu-test) for the detection of environmental mutagens and carcinogens. Mutat Res 147: 219-229.

75. Quillardet $P$, de Bellecombe C, Hofnung M (1985) The SOS Chromotest, a colorimetric bacterial assay for genotoxins: validation study with 83 compounds. Mutat Res 147: 79-95.

76. Quillardet P, Huisman O, D'Ari R, Hofnung M (1982) SOS chromotest, a direct assay of induction of an SOS function in Escherichia coli K-12 to measure genotoxicity. Proc Natl Acad Sci U S A 79: 5971-5975.

77. Gartiser S, Brinker L (1996) Sewage Contaminating Substances and wastewater situation in hospitals. FE No. 10206 514, Federal Ministry for the Environment, Nature Conservation and Nuclear Safety and the Federal Environment Agency, Berlin.

78. Jager I, Gartiser S, Willmund RH (1996a) Use of biological testing of effluents of textile industry. Acta hydrochim Hydrobiol 24: 22-30.

79. Miltenburger HG (1997) Quantitative Beurteilung von Mutagenitat in Abwasserstromen der chemischen Industrie. Final report VCI/Verband der chemischen Industrie, Roßdort (German).

80. Strniste GF, Chen DJ, Okinaka RT (1982) Genotoxic effects of sunlightactivated waste water in cultured mammalian cells. J Natl Cancer Inst 69: 199203.

81. Waters LC, Schenley RL, Owen BA, Walsh PJ, Hsie AW, et al. (1989) Biotesting of wastewater: a comparative study using the Salmonella and $\mathrm{CHO}$ assay systems. Environ Mol Mutagen 14: 254-263.

82. Venegas W, Garcia MD (1994) Genotoxic effects induced in cultured Chinese hamster ovary $(\mathrm{CHO})$ cells by contaminated aquatic environments. Biol Res 27: 217-223.

83. Nobukawa T, Sanukida S (2000) The genotoxicity of by-products by chlorination and ozonation of the river water in the prsesnce of bromide ions. Water Science and Techonology 42: 259-264.

84. Singh NP, McCoy MT, Tice RR, Schneider EL (1988) A simple technique for quantitation of low levels of DNA damage in individual cells. Exp Cell Res 175: 184-191.

85. Pandrangi R, Petras M, Ralph S, Vrzoc M (1995) Alkaline single cell gel (comet) assay and genotoxicity monitoring using bullheads and carp. Environ Mol Mutagen 26: 345-356.

86. Devaux A, Pesonen M, Monod G (1997) Alkaline comet assay in rainbow trout hepatocytes. Toxicol In Vitro 11: 71-79.

87. Belpaeme K, Cooreman K, Kirsch-Volders M (1998) Development and validation of the in vivo alkaline comet assay for detecting genomic damage in marine flatfish. Mutat Res 415: 167-184.

88. Risso-de Faverney C, Devaux A, Lafaurie M, Girard JP, Bailly B, et al. (2001) Cadmium induces apoptosis and genotoxicity in rainbow trout hepatocytes through generation of reactive oxygene species. Aquat Toxicol 53: 65-76.

89. Wittekindt E, Saftic F, Mattthess C, Fischer B, Hansen PD, et al. (2000) In situ investigations for the detection of genotoxic potential in selected surface water with the DNA alkaline unwinding assay using fish cells, early life stage of fish crustaceae and mussels: 217.

90. Everaarts JM, Sarkar A (1996) DNA damage as a biomarker of marine pollution: strand breaks in seastars (Asterias rubens) from the North Sea. Water Science and Technology 34: 157-162.

91. Nagpure NS, Pandey S, Sharma S (2005) Single cell gel electrophoresis (SCGE) or comet assay. In: Kapour, D and Nagpour, N.S (eds), Training on genotoxic assays in fishes. National Bureau of Genetic Resources.Dilkusha, Telibagh, India: 68.

92. Arockia R, Selvanayagam M (1998) Genotoxic effects of fenvalerate on the chromosomes of fish Oreochromis mossambicus (peters). Poll Res 17: 119122.

93. Anitha B, Chandra N, Gopinath PM, Durairaj G (2000) Genotoxicity evaluation of heat shock in Gold fish (Carassius auratus). Mutat Res Genet Toxico Environ Mutag 469: 1-8.

94. Schmid W (1975) The micronucleus test. Mutat Res 31: 9-15

95. Chung YS, Ichikawa K, Utsumi H (1997) Application of micronucleus in vitro assay to micropollutants in river water. Water Science and Technology 35 9-13.

96. Kohlpoth M, Rusche B, Nüsse M (1999) Flow cytometric measurement of micronuclei induced in a permanent fish cell line as a possible screening test for the genotoxicity of industrial waste waters. Mutagenesis 14: 397-402.

97. Odeigah PG, Osanyinpeju AO, Osanyipeju AO (1995) Genotoxic effects of two industrial effluents and ethyl methane sulfonate in Clarias lazera. Food Chem Toxicol 33: 501-505.

98. Tuvikene A, Huuskonen S, Koponen K, Ritola O, Mauer U, et al. (1999) Oil shale processing as a source of aquatic pollution: monitoring of the biologic effects in caged and feral freshwater fish. Environ Health Perspect 107: 745752.

99. Kumar R, Pandey S, Sharma S (2005) Study of sister chromatid exchanges for assessment of genotoxicity. In: Kapour D and Nagpour NS (eds), Training on genotoxic assays in fishes. National Bureau of Genetic Resources. Dilkusha Telibagh, India: 68

100. Jha AN, Cheung VV, Foulkes ME, Hill SJ, Depledge MH (2000) Detection of genotoxins in the marine environment: adoption and evaluation of an integrated approach using the embryo-larval stages of the marine mussel, Mytilus edulis. Mutat Res 464: 213-228.

101. Jha AN, Hagger JA, Hill SJ (2000) Tributyltin induces cytogenetic damage in the early life stages of the marine mussel, Mytilus edulis. Environ Mol Mutagen 35: 343-350.

102. Zakour HR, Landolt ML, Kocan RM (1984) Sister chromatid exchange analysis in cultured peripheral blood leukocytes of the coldwater marine fish, Pacific staghorn sculpin (Leptocottus armatus): a feasible system for assessing genotoxic marine pollutants. Basic Life Sci 29 Pt B: 493-508.

103.Winn RN, Norris MB, Brayer KJ, Torres C, Muller SL (2000) Detection of mutations in transgenic fish carrying a bacteriophage lambda cll transgene target. Proc Natl Acad Sci U S A 97: 12655-12660.

104. Bhaskaran A, May D, Rand-Weaver M, Tyler CR (1999) Fish p53 as a possible biomarker for genotoxins in the aquatic environment. Environ Mol Mutagen 33: $177-184$.

105. Bhaskaran A, May D, Rand-Weaver M, Tyler CR (2000) Molecular characterization of the first non-mammalian p73 cDNA. Comp Biochem Physiol B Biochem Mol Biol 126: 49-57.

106. Kennerley GA, Parry JM (1994) Analysis of benzo[a]pyrene induced mutations by the use of Restriction-Site Mutation assays in aquatic species. Mutat Res 307: 223-228.

107. Mascini M, Palchetti I, Marrazza G (2001) DNA electrochemical biosensors Fresenius J Anal Chem 369: 15-22.

108. Hutchinson TH, Jha AN, Mackay JM, Elliott BM, Dixon DR (1998) Assessment of developmental effects, cytotoxicity and genotoxicity in the marine polychaete (Platynereis dumerilii) exposed to disinfected municipal sewage effluent. Mutat Res 399: 97-108

109. Rodgers BE, Baker RJ (2000) Frequencies of micronuclei in bank voles from zones of high radiation at Chernobyl, Ukraine. Environ Toxicol Chem 19: 1644-1648. 
Citation: Akpoilih BU (2013) Fish Ecogenotoxicology: An Emerging Science, an Emerging Tool for Environmental Monitoring and Risk Assessment. J Environ Anal Toxicol 3:165. doi:10.4172/2161-0525.1000165

110. Shugart L, Theodorakis C (1994) Environmental genotoxicity: probing the underlying mechanisms. Environ Health Perspect 12: 13-17.

111. Shugart LR, Theodorakis CW (1996) Genetic ecotoxicology: The genotypic diversity approach. Comp Biochem Physiol 113: 273-276.

112. Muller L, Kasper P, Madle S (1991) The quality of genotoxicity testing of drugs. Experiences of a regulatory agency with new and old compounds. Mutagenesis 6: 143-149.

113. Tennant RW, Margolin BH, Shelby MD, Zeiger E, Haseman JK, et al. (1987) Prediction of chemical carcinogenicity in rodents from in vitro genetic toxicity assays. Science 236: 933-941.

114. Scott D, Galloway SM, Marshall RR, Ishidate M Jr, Brusick D, et al. (1991) International Commission for Protection Against Environmental Mutagens and Carcinogens. Genotoxicity under extreme culture conditions. A report from ICPEMC Task Group 9. Mutat Res 257: 147-205.

115. Allen JW, Liang JC, Carrano AV, Preston RJ (1986) Review of literature on chemical-induced aneuploidy in mammalian male germ cells. Mutat Res 167 123-137.

116. Nath J, Tucker JD, Hando JC (1995) Y chromosome aneuploidy, micronuclei, kinetochores and aging in men. Chromosoma 103: 725-731.
117. Abend M, Kehe K, Riedel M, Beuningen DV (2000) Correlation of micronucleus and apoptosis assays with reproductive cell death can be improved by considering other modes of death. Int J Rad Biol 76: 249-259.

118. Marzin D (1999) New approaches to estimating the mutagenic potential of chemicals. Cell Biol Toxicol 15: 359-365.

119. Shimizu N, Shimura T, Tanaka T (2000) Selective elimination of acentric double minutes from cancer cells through the extrusion of micronuclei. Muta Res 448: 81-90.

120. Butterworth BE, Ashby J, Bermudez E, Casciano D, Mirsalis J, et al. (1987) A protocol and guide for the in vivo rat hepatocyte DNA-repair assay. Mutat Res 189: 123-133.

121. Martelli A, Campart GB, Carrozzino R, Ghia M, Mattioli F, et al. (2000) Evaluation of flutamide genotoxicity in rats and in primary human hepatocytes. Pharmacol Toxicol 86: 129-134.

122. Sinha N (2005) Detection of apoptosis and health monitoring in fishes. In Kapour, D and Nagpour, N.S (eds.), Training on genotoxic assays in fishes. National Bureau of Genetic Resources. Dilkusha, Telibagh, India 68. 